\title{
An efficient synthesis and biological study of substituted 8-chloro-5-methoxy/8-chloro-4H-1,4-benzothiazines, their sulphones and ribofuranosides
}

\author{
NISHIDHA KHANDELWAL*, ABHILASHA, NAVEEN GAUTAM and D C GAUTAM \\ Department of Chemistry, University of Rajasthan, Jawahar LaL Nehru Marg, Jaipur 302 004, India \\ e-mail: nishidha.khandelwal@gmail.com; abhilashasuraj@gmail.com; ngautam70@yahoo.co.in; \\ drdcgautam@yahoo.co.in
}

MS received 29 December 2011; revised 29 May 2012; accepted 20 July 2012

\begin{abstract}
Chloro-5-methoxy/8-chloro-4H-1,4-benzothiazines were synthesized by condensation followed by oxidative cyclisation of 2-amino-6-chloro-3-methoxy/2-amino-3-chlorobenzenethiol with $\beta$-diketones/ $\beta$ ketoesters in the presence of dimethyl sulphoxide. By treating 4H-1,4-benzothiazines with $30 \%$ hydrogen peroxide in glacial acetic acid, 4H-1,4-benzothiazine-1,1-dioxides (sulphones) were synthesized. The 4H-1,4benzothiazines have also been used as a base to prepare ribofuranosides by the reaction with $\beta-\mathrm{D}$-ribofuranose1 -acetate-2,3,5-tribenzoate. All the synthesized compounds have been characterized by spectral and elemental analysis and have been examined for antimicrobial and anthelmintic activity.
\end{abstract}

Keywords. 4H-1,4-benzothiazines; sulphones; ribofuranosides; antimicrobial activity; anthelmintic activity.

\section{Introduction}

Six-membered heterocyclic compounds have occupied a prominent place among various classes of organic compounds for their diverse biological activities. Among a wide variety of heterocycles that have been explored developing pharmaceutically important molecules, 4H-1,4-benzothiazines, ${ }^{1-8}$ their sulphones and rifuranosides have played an important role in medicinal chemistry. Benzothiazines possess a fold along nitrogen-sulphur axis which is one of the structural specificities responsible for pharmacological activities. ${ }^{9-15}$ It has stimulated our interest to convert benzothiazines to sulphones to understand oxidation behaviour of $4 \mathrm{H}-1,4$-benzothiazines and to investigate changes in infrared and nuclear magnetic resonance spectra caused by the conversion of sulphide linkage to sulphones. $4 \mathrm{H}-1,4$-benzothiazines serve as heterocyclic base for the formation of ribofuranosides on treatment with sugar ( $\beta$-D-ribofuranosyl-1-acetate2,3,5-tribenzoate). All these compounds are extensively used as sedatives, anthelmintic, antiulcer, anticancer, antibacterial, antifungal, etc. A slight change in the substitution pattern in the benzothiazine nucleus cause distinguishable difference in their biological activities. The newly synthesized compounds have been screened for antimicrobial and anthelmintic activity.

*For correspondence

\section{Materials and methods}

\subsection{Experimental}

All the melting points were determined in an open capillary tubes and are uncorrected. ${ }^{1} \mathrm{H}$ NMR and ${ }^{13} \mathrm{C}$ NMR spectra (by broad band proton decoupling technique) were recorded on JEOL AL-300 spectrometer at frequencies of (300.40 MHz and 75.45 MHz) respectively, in dimethylsulphoxide- $\mathrm{d}_{6}$ using TMS (tetramethyl silane) as an internal standard. IR spectra were recorded in $\mathrm{KBr}$ on SHIMADZU 8400 S FTIR spectrophotometer. Mass spectra were recorded on WATERS (micromass MS technologies) Q-T by electron spray ionization. ${ }^{19} \mathrm{~F}$ NMR spectra were recorded in $\mathrm{CDCl}_{3}$ using $\mathrm{CF}_{3} \mathrm{COOH}$ as standard compound. Purity of synthesized compounds was checked by TLC (thinlayer chromatography) using silica gel ' $\mathrm{G}$ ' as adsorbent, visualizing these by UV light or in an iodine chamber.

\subsection{General procedure of synthesis of substituted 4H-1,4-benzothiazines $(\mathbf{3 a}-\mathbf{d})$}

To 2-amino-5-chloro-2-methoxy/3-chlorobenzenethiol $(0.01 \mathrm{~mol})(\mathbf{1 a}-\mathbf{b})$, a stirred suspension of the appropriate $\beta$-diketones/ $\beta$-ketoesters (2a-d) in DMSO $(5 \mathrm{~mL})$ was added and the resulting mixture was refluxed for $2-3 \mathrm{~h}$. The reaction mixture was concentrated, cooled 
down to room temperature and filtered. The product was washed with petroleum ether and crystallized from methanol.

2.2a 8-Chloro-2-trifluoroacetyl-3-trifluoromethyl-5methoxy-4H-1,4-benzothiazine (3a): Brown solid; m.p.: $65^{\circ} \mathrm{C}$; yield: 56\%, IR (KBr): $v 3350(\mathrm{~N}-\mathrm{H})$, $1595(>\mathrm{C}=\mathrm{O}), 2965$ and $2875\left(-\mathrm{OCH}_{3}\right), 1285$ and 1020 (C-O-C), 1335 and $1100 \mathrm{~cm}^{-1}\left(-\mathrm{CF}_{3}\right)$ and $780 \mathrm{~cm}^{-1}(\mathrm{C}-\mathrm{Cl}) ;{ }^{1} \mathrm{H}$ NMR spectral data $(300.40 \mathrm{MHz}$, $\mathrm{Me}_{2} \mathrm{SO}-\mathrm{d}_{6}, \delta \mathrm{ppm}$ from TMS $): \delta 8.93(\mathrm{~s}, 1 \mathrm{H}, \mathrm{N}-\mathrm{H})$, 8.10-6.39 (m, 2H, Ar-H), $3.87\left(\mathrm{~s}, 3 \mathrm{H},-\mathrm{OCH}_{3}\right) ;{ }^{13} \mathrm{C}$ NMR (75.45 MHz, $\mathrm{CDCl}_{3}, \delta \mathrm{ppm}$ from TMS): $\delta 116.2$ $(\mathrm{C}-2), 196.5(\mathrm{C}=\mathrm{O}$ at $\mathrm{C}-2), 128.8\left(\mathrm{CF}_{3}\right.$ at $\left.\mathrm{C}-2\right), 136.3$ (C-3), $114.9\left(\mathrm{CF}_{3}\right.$ at C-3), $147.0(\mathrm{C}-5), 56.0\left(\mathrm{OCH}_{3}\right.$ at C-5), 113.1 (C-6), 120.2 (C-7), 127.6 (C-8); ${ }^{19} \mathrm{~F}$ NMR $\left(282.65 \mathrm{MHz}, \mathrm{CDCl}_{3}\right): \delta-61.93\left(\mathrm{~s}, 3 \mathrm{~F}, \mathrm{CF}_{3}\right) ; \mathrm{MS}$ (FAB) $10 \mathrm{kV}, \mathrm{m} / \mathrm{z}$ (rel. int.): $377[\mathrm{M}]^{+}, 379[\mathrm{M}+2]^{+}$, 279 (41), 376 (27), 97 (100), 281 (56), 248 (36); 'Anal. Calcd for $\mathrm{C}_{12} \mathrm{H}_{6} \mathrm{NO}_{2} \mathrm{~F}_{6} \mathrm{SCl}$ : C, 38.14; H, 1.59; N, 3.71, Found: C, 38.46; H,1.60; N, 3.73'.

2.2b Ethyl-8-chloro-5-methoxy-3-propyl-4H-1,4benzothiazine-2-carboxylate (3b): Red solid; m.p.: $90^{\circ} \mathrm{C}$; yield: $58 \%$, IR $(\mathrm{KBr}): v 3310(\mathrm{~N}-\mathrm{H}), 1590$ $(>\mathrm{C}=\mathrm{O}), 2955$ and $2830\left(-\mathrm{OCH}_{3}\right), 1280$ and 1030 (C-O-C), and $750 \mathrm{~cm}^{-1}(\mathrm{C}-\mathrm{Cl}) ;{ }^{1} \mathrm{H}$ NMR spectral data (300.40 MHz, $\mathrm{Me}_{2} \mathrm{SO}_{-} \mathrm{d}_{6}, \delta$ ppm from TMS): $\delta 8.73$ (s, 1H, N-H), 8.02-6.34 (m, 2H, Ar-H), 3.86 (s, 3H, $\left.-\mathrm{OCH}_{3}\right), 2.51$ (t, $2 \mathrm{H}, \mathrm{CH}_{2}$ (terminal) of $\mathrm{C}_{3} \mathrm{H}_{7}$ at $\mathrm{C}-3$ ), 1.60 (sextet, $2 \mathrm{H}, \mathrm{CH}_{2}$ (centre) of $\mathrm{C}_{3} \mathrm{H}_{7}$ at $\mathrm{C}-3$ ), 1.20 (t, $3 \mathrm{H}, \mathrm{CH}_{3}$ of $\mathrm{C}_{3} \mathrm{H}_{7}$ at C-3), 4.95 (q, $2 \mathrm{H}, \mathrm{CH}_{2}$ of $\mathrm{OC}_{2} \mathrm{H}_{5}$ at $\mathrm{C}-2), 1.78$ (t, 3H, $\mathrm{CH}_{3}$ of $\mathrm{OC}_{2} \mathrm{H}_{5}$ at $\left.\mathrm{C}-2\right) ;{ }^{13} \mathrm{C} \mathrm{NMR}$ (75.45 MHz, $\mathrm{CDCl}_{3}, \delta \mathrm{ppm}$ from TMS): $\delta 105.8$ (C-2), $165.0(\mathrm{C}=\mathrm{O}$ at $\mathrm{C}-2), 59.2\left(\mathrm{CH}_{2}\right.$ of $\mathrm{OC}_{2} \mathrm{H}_{5}$ at $\left.\mathrm{C}-2\right)$, $13.4\left(\mathrm{CH}_{3}\right.$ of $\mathrm{OC}_{2} \mathrm{H}_{5}$ at C-2), $143.5(\mathrm{C}-3), 33.8\left(\mathrm{CH}_{2}\right.$ (terminal) of $\mathrm{C}_{3} \mathrm{H}_{7}$ at C-3), $17.5\left(\mathrm{CH}_{2}\right.$ (middle) of $\mathrm{C}_{3} \mathrm{H}_{7}$ at C-3), $14.4\left(\mathrm{CH}_{3}\right.$ (terminal) of $\mathrm{C}_{3} \mathrm{H}_{7}$ at $\left.\mathrm{C}-3\right), 146.1$ (C-5), $56.4\left(\mathrm{OCH}_{3}\right.$ at C-5), 112.1 (C-6), 119.2 (C-7), 126.2 (C-8); MS (FAB) $10 \mathrm{kV}, \mathrm{m} / \mathrm{z}$ (rel. int.): $327[\mathrm{M}]^{+}$, $329[\mathrm{M}+2]^{+}, 326(48), 253$ (36), 248 (43), 73 (100), 221 (63); 'Anal. Calcd for $\mathrm{C}_{15} \mathrm{H}_{18} \mathrm{NO}_{3} \mathrm{ClS}$ : C, 54.96; H, 5.49; N, 4.27, Found: C, 55.27; H, 5.51; N, 4.34'.

2.2c Methyl-8-chloro-3-ethyl-5-methoxy-4H-1,4benzothiazine-2-carboxylate (3c): Red solid; m.p.: $80^{\circ} \mathrm{C}$; yield: $63 \%$, IR $(\mathrm{KBr}): v 3300(\mathrm{~N}-\mathrm{H}), 1580$ $(>\mathrm{C}=\mathrm{O}), 2960$ and $2846\left(-\mathrm{OCH}_{3}\right), 1252$ and 1035 $(\mathrm{C}-\mathrm{O}-\mathrm{C})$ and $740 \mathrm{~cm}^{-1}(\mathrm{C}-\mathrm{Cl}) ;{ }^{1} \mathrm{H}$ NMR spectral data $\left(300.40 \mathrm{MHz}, \mathrm{Me}_{2} \mathrm{SO}-\mathrm{d}_{6}, \delta \mathrm{ppm}\right.$ from TMS): $\delta 8.68$ (s, 1H, N-H), 8.45-6.42 (m, 2H, Ar-H), 4.01 (s, 3H,
$-\mathrm{OCH}_{3}$ at C-2), $2.42\left(\mathrm{q}, 2 \mathrm{H}, \mathrm{CH}_{2}\right.$ of $\mathrm{C}_{2} \mathrm{H}_{5}$ at $\left.\mathrm{C}-3\right)$, $1.45\left(\mathrm{t}, 3 \mathrm{H}, \mathrm{CH}_{3}\right.$ of $\mathrm{C}_{2} \mathrm{H}_{5}$ at $\left.\mathrm{C}-3\right), 3.72\left(\mathrm{~s}, 3 \mathrm{H},-\mathrm{OCH}_{3}\right.$ at $\mathrm{C}-5) ;{ }^{13} \mathrm{C} \mathrm{NMR}\left(75.45 \mathrm{MHz}, \mathrm{CDCl}_{3}, \delta \mathrm{ppm}\right.$ from TMS): $108.1(\mathrm{C}-2), 164.9(\mathrm{C}=\mathrm{O}$ at $\mathrm{C}-2), 50.3\left(\mathrm{CH}_{3}\right.$ at C-2), $141.6(\mathrm{C}-3), 24.0\left(\mathrm{CH}_{2}\right.$ of $\mathrm{C}_{2} \mathrm{H}_{5}$ at C-3), 8.7 $\left(\mathrm{CH}_{3}\right.$ of $\mathrm{C}_{2} \mathrm{H}_{5}$ at $\left.\mathrm{C}-3\right), 55.9\left(\mathrm{OCH}_{3}\right.$ at C-5), $147.3(\mathrm{C}-$ 5), 113.2 (C-6), 120.1 (C-7), 127.4 (C-8); MS (FAB) $10 \mathrm{kV}, \mathrm{m} / \mathrm{z}$ (rel. int.): 299 [M] $^{+}, 301[\mathrm{M}+2]^{+}, 298$ (28), 270 (73), 264 (31), 240 (65), 59 (100); 'Anal. Calcd for $\mathrm{C}_{13} \mathrm{H}_{14} \mathrm{NO}_{3} \mathrm{SCl}: \mathrm{C}, 52.08 ; \mathrm{H}, 4.67 ; \mathrm{N}, 4.67$, Found: C, 52.23; H, 4.71; N, 4.75'.

\section{2d 5-Chloro-3-ethyl-2-propionyl-4H-1,4-benzo-} thiazine (3d): Brown solid; m.p.: $70^{\circ} \mathrm{C}$; yield: $62 \%$, IR $(\mathrm{KBr})$ : v $3290(\mathrm{~N}-\mathrm{H}), 1585(>\mathrm{C}=\mathrm{O}), 2980\left(\mathrm{CH}_{3}\right)$, and $720 \mathrm{~cm}^{-1}(\mathrm{C}-\mathrm{Cl}) ;{ }^{1} \mathrm{H}$ NMR spectral data $(300.40 \mathrm{MHz}$, $\mathrm{Me}_{2} \mathrm{SO}_{-} \mathrm{d}_{6}, \delta \mathrm{ppm}$ from TMS): $\delta 8.44(\mathrm{~s}, 1 \mathrm{H}, \mathrm{N}-\mathrm{H})$, 8.32-6.16 (m, 3H, Ar-H), 3.17 (q, $2 \mathrm{H}, \mathrm{CH}_{2}$ of $\mathrm{C}_{2} \mathrm{H}_{5}$ at C-2), 1.81 (t, $3 \mathrm{H}, \mathrm{CH}_{3}$ of $\mathrm{OC}_{2} \mathrm{H}_{5}$ at C-2), 2.51 (q, $2 \mathrm{H}, \mathrm{CH}_{2}$ of $\mathrm{C}_{2} \mathrm{H}_{5}$ at C-3), $1.31\left(\mathrm{t}, 3 \mathrm{H}, \mathrm{CH}_{3}\right.$ of $\mathrm{C}_{2} \mathrm{H}_{5}$ at $\mathrm{C}-3) ;{ }^{13} \mathrm{C}$ NMR $\left(75.45 \mathrm{MHz}, \mathrm{CDCl}_{3}, \delta \mathrm{ppm}\right.$ from TMS): $115.5(\mathrm{C}-2), 197.6(\mathrm{C}=\mathrm{O}$ at $\mathrm{C}-2), 30.5\left(\mathrm{CH}_{2}\right.$ of $\mathrm{C}_{2} \mathrm{H}_{5}$ at C-2), $7.1\left(\mathrm{CH}_{3}\right.$ of $\mathrm{C}_{2} \mathrm{H}_{5}$ at C-2), 141.1 (C-3), $24.2\left(\mathrm{CH}_{2}\right.$ of $\mathrm{C}_{2} \mathrm{H}_{5}$ at C-3), $8.6\left(\mathrm{CH}_{3}\right.$ of $\mathrm{C}_{2} \mathrm{H}_{5}$ at C-3), 120.8 (C-5), 126.6 (C-6), 120.3 (C-7), 128.0 (C-8); MS (FAB) $10 \mathrm{kV}, \mathrm{m} / \mathrm{z}$ (rel. int.): $267[\mathrm{M}]^{+}, 269[\mathrm{M}+2]^{+}$, 266 (22), 238 (44), 210 (58), 232 (76), 57 (100); 'Anal. Calcd for $\mathrm{C}_{13} \mathrm{H}_{14} \mathrm{NOSCl}$ : C, 58.31; H, 5.23; N, 5.23, Found: C, 53.58; H, 5.26; N, 5.28'.

\subsection{General procedure of synthesis of 4H-1,4-benzothiazine sulphones $(\mathbf{4 a - d})$}

A mixture of substituted $4 H$-1,4-benzothiazines (3a-d) $(0.01 \mathrm{~mol})$, glacial acetic acid $(20 \mathrm{~mL})$ and $30 \%$ hydrogen peroxide $(5 \mathrm{~mL})$ was refluxed for $15 \mathrm{~min}$. Heating was stopped and another lot of hydrogen peroxide $(5 \mathrm{~mL})$ was added. The reaction mixture was again refluxed for further $4 \mathrm{~h}$. The contents were poured into a beaker containing crushed ice. Residue obtained was filtered and washed with water and recrystallized from ethanol.

2.3a 8-Chloro-2-trifluoroacetyl-3-trifluoromethyl-5methoxy-4H-1,4-benzothiazine-1,1-dioxide (4a): Brown solid; m.p.: $280^{\circ} \mathrm{C}$; yield: $48 \%$, IR $(\mathrm{KBr}): v$ $3380(\mathrm{~N}-\mathrm{H}), 1645(\mathrm{C}=\mathrm{O}), 2950$ and $2838\left(-\mathrm{OCH}_{3}\right)$, 1250 and $1030(\mathrm{C}-\mathrm{O}-\mathrm{C}), 1375,1120\left(-\mathrm{CF}_{3}\right), 790$ (C$\mathrm{Cl}), 1200$ and $1140\left(\mathrm{SO}_{2} \mathrm{sym}\right), 1080 \mathrm{~cm}^{-1}(\mathrm{C}-\mathrm{S}) ;{ }^{1} \mathrm{H}$ NMR spectral data $\left(300.40 \mathrm{MHz}, \mathrm{Me}_{2} \mathrm{SO}_{-} \mathrm{d}_{6}, \delta \mathrm{ppm}\right.$ from TMS): $\delta 9.11(\mathrm{~s}, 1 \mathrm{H}, \mathrm{N}-\mathrm{H}), 8.25-6.28(\mathrm{~m}, 2 \mathrm{H}$, $\mathrm{Ar}-\mathrm{H}), 3.91\left(\mathrm{~s}, 3 \mathrm{H},-\mathrm{OCH}_{3}\right) ;{ }^{13} \mathrm{C} \mathrm{NMR}(75.45 \mathrm{MHz}$, 
$\mathrm{CDCl}_{3}, \delta$ ppm from TMS $): \delta 100(\mathrm{C}-2), 195.6(\mathrm{C}=\mathrm{O}$ at $\mathrm{C}-2), 129.1\left(\mathrm{CF}_{3}\right.$ at $\left.\mathrm{C}-2\right), 154.3(\mathrm{C}-3), 115.6\left(\mathrm{CF}_{3}\right.$ at $\mathrm{C}-3), 146.5(\mathrm{C}-5), 55.2\left(\mathrm{OCH}_{3}\right.$ at $\left.\mathrm{C}-5\right), 121.3(\mathrm{C}-$ 6), $119.2(\mathrm{C}-7), 124.6(\mathrm{C}-8) ;{ }^{19} \mathrm{~F}$ NMR $(282.65 \mathrm{MHz}$, $\left.\mathrm{CDCl}_{3}\right): \delta-62.11\left(\mathrm{~s}, 3 \mathrm{~F}, \mathrm{CF}_{3}\right) ; \mathrm{MS}(\mathrm{FAB}) 10 \mathrm{kV}, \mathrm{m} / \mathrm{z}$ (rel. int.): $409[\mathrm{M}]^{+}, 411[\mathrm{M}+2]^{+}, 311$ (54), 340 (38), 313 (68), 97 (100); 'Anal. Calcd for $\mathrm{C}_{12} \mathrm{H}_{6} \mathrm{NO}_{4} \mathrm{~F}_{6} \mathrm{SCl}$ : C, 35.16; H, 1.46; N, 3.41, Found: C, 35.48; H,1.50; $\mathrm{N}, 3.47$ '.

2.3b Ethyl-8-chloro-5-methoxy-3-propyl-4H-1,4benzothiazine-2-carboxylate-1,1-dioxide (4b): Reddish yellow solid; m.p.: $293^{\circ} \mathrm{C}$; yield: $50 \%$, IR (KBr): $v$ $3340(\mathrm{~N}-\mathrm{H}), 2973$ and $2870\left(-\mathrm{OCH}_{3}\right), 1630(>\mathrm{C}=\mathrm{O})$, $1180,1150\left(\mathrm{SO}_{2} \mathrm{sym}\right), 1085(\mathrm{C}-\mathrm{S})$ and $735 \mathrm{~cm}^{-1}(\mathrm{C}-$ $\mathrm{Cl}) ;{ }^{1} \mathrm{H}$ NMR spectral data $\left(300.40 \mathrm{MHz}, \mathrm{Me}_{2} \mathrm{SO}-\mathrm{d}_{6}, \delta\right.$ ppm from TMS): $\delta 8.97(\mathrm{~s}, 1 \mathrm{H}, \mathrm{N}-\mathrm{H}), 8.07-6.44(\mathrm{~m}$, $2 \mathrm{H}, \mathrm{Ar}-\mathrm{H}), 4.43\left(\mathrm{~s}, 3 \mathrm{H},-\mathrm{OCH}_{3}\right), 2.23\left(\mathrm{t}, 2 \mathrm{H}, \mathrm{CH}_{2}\right.$ (terminal) of $\mathrm{C}_{3} \mathrm{H}_{7}$ at C-3), 1.45 (sextet, $2 \mathrm{H}, \mathrm{CH}_{2}$ (middle) of $\mathrm{C}_{3} \mathrm{H}_{7}$ at C-3), 1.65 (t, 3H, $\mathrm{CH}_{3}$ of $\mathrm{C}_{3} \mathrm{H}_{7}$ at C-3), 4.22 (q, $2 \mathrm{H}, \mathrm{CH}_{2}$ of $\mathrm{OC}_{2} \mathrm{H}_{5}$ at $\left.\mathrm{C}-2\right), 1.89\left(\mathrm{t}, 3 \mathrm{H}, \mathrm{CH}_{3}\right.$ of $\mathrm{OC}_{2} \mathrm{H}_{5}$ at $\left.\mathrm{C}-2\right) ;{ }^{13} \mathrm{C}$ NMR $\left(75.45 \mathrm{MHz}, \mathrm{CDCl}_{3}, \delta\right.$ ppm from TMS): $\delta 99(\mathrm{C}-2), 197.5(\mathrm{C}=\mathrm{O}$ at $\mathrm{C}-2), 30.2$ $\left(\mathrm{CH}_{2}\right.$ of $\mathrm{OC}_{2} \mathrm{H}_{5}$ at $\left.\mathrm{C}-2\right), 7.4\left(\mathrm{CH}_{3}\right.$ of $\mathrm{OC}_{2} \mathrm{H}_{5}$ at C-2), 158 (C-3), $33.8\left(\mathrm{CH}_{2}\right.$ (terminal) of $\mathrm{C}_{3} \mathrm{H}_{7}$ at $\left.\mathrm{C}-3\right), 18.0$ $\left(\mathrm{CH}_{2}\right.$ (middle) of $\mathrm{C}_{3} \mathrm{H}_{7}$ at $\left.\mathrm{C}-3\right), 14.1\left(\mathrm{CH}_{3}\right.$ (terminal) of $\mathrm{C}_{3} \mathrm{H}_{7}$ at C-3), 147.1 (C-5), $56.4\left(\mathrm{OCH}_{3}\right.$ at C-5), 121.1 (C-6), 120.9 (C-7), 124.9 (C-8); MS (FAB) $10 \mathrm{kV}, \mathrm{m} / \mathrm{z}$ (rel. int.) : $359[\mathrm{M}]^{+}, 361[\mathrm{M}+2]^{+}, 358$ (20), 286 (39), 316 (28), 73 (100); 'Anal. Calcd for $\mathrm{C}_{15} \mathrm{H}_{18} \mathrm{NO}_{5} \mathrm{ClS}$ : C, 50.06; H, 5.00; N, 3.89, Found: C, 50.31; H, 5.06; N, 3.93'.

2.3c Methyl-8-chloro-3-ethyl-5-methoxy-4H-1,4benzothiazine-2-carboxylate-1,1-dioxide (4c): Brown solid; m.p.: $275^{\circ} \mathrm{C}$; yield: $46 \%$, IR (KBr): $v 3360$ $(\mathrm{N}-\mathrm{H}), 1610(>\mathrm{C}=\mathrm{O}), 2965$ and $2865\left(-\mathrm{OCH}_{3}\right)$ and $760 \mathrm{~cm}^{-1}(\mathrm{C}-\mathrm{Cl}) ;{ }^{1} \mathrm{H}$ NMR spectral data $(300.40 \mathrm{MHz}$, $\mathrm{Me}_{2} \mathrm{SO}_{-} \mathrm{d}_{6}, \delta \mathrm{ppm}$ from TMS): $\delta 8.91(\mathrm{~s}, 1 \mathrm{H}, \mathrm{N}-\mathrm{H})$, 8.65-6.72 (m, 2H, Ar-H), $3.96\left(\mathrm{~s}, 3 \mathrm{H},-\mathrm{OCH}_{3}\right.$ at C-2), 2.58 (q, $2 \mathrm{H}, \mathrm{CH}_{2}$ of $\mathrm{C}_{2} \mathrm{H}_{5}$ at C-3), 1.59 (t, $3 \mathrm{H}, \mathrm{CH}_{3}$ of $\mathrm{C}_{2} \mathrm{H}_{5}$ at $\left.\mathrm{C}-3\right), 3.82\left(\mathrm{~s}, 3 \mathrm{H},-\mathrm{OCH}_{3}\right.$ at $\left.\mathrm{C}-5\right) ;{ }^{13} \mathrm{C} \mathrm{NMR}$ (75.45 MHz, $\mathrm{CDCl}_{3}, \delta \mathrm{ppm}$ from TMS): $92(\mathrm{C}-2)$, $165.2\left(\mathrm{C}=\mathrm{O}\right.$ of $\mathrm{OCH}_{3}$ at $\left.\mathrm{C}-2\right), 50.7\left(\mathrm{CH}_{3}\right.$ at $\left.\mathrm{C}-2\right)$, 159.1 (C-3), $23.6\left(\mathrm{CH}_{2}\right.$ of $\mathrm{C}_{2} \mathrm{H}_{5}$ at C-3), $9.1\left(\mathrm{CH}_{3}\right.$ of $\mathrm{C}_{2} \mathrm{H}_{5}$ at $\left.\mathrm{C}-3\right), 56.3\left(\mathrm{OCH}_{3}\right.$ at $\left.\mathrm{C}-5\right), 147.5$ (C-5), 121.2 (C-6), 121.0 (C-7), 124.9 (C-8); MS (FAB) $10 \mathrm{kV}$, $\mathrm{m} / \mathrm{z}$ (rel. int.): $331[\mathrm{M}]^{+}, 333[\mathrm{M}+2]^{+}, 330(25), 302$ (71), 296 (36), 272 (61), 59 (100); 'Anal. Calcd for $\mathrm{C}_{13} \mathrm{H}_{14} \mathrm{NO}_{5} \mathrm{SCl}: \mathrm{C}, 47.05 ; \mathrm{H}, 4.22$; N, 4.22, Found: C, 47.29; H, 4.26; N, 4.33'. 2.3d 5-Chloro-3-ethyl-2-propionyl-4H-1,4-benzothiazine-1,1-dioxide (4d): Black solid; m.p.: $286^{\circ} \mathrm{C}$; yield: 52\%, IR (KBr): v $3310(\mathrm{~N}-\mathrm{H}), 1645(>\mathrm{C}=\mathrm{O})$, $2985\left(\mathrm{CH}_{3}\right)$, and $740 \mathrm{~cm}^{-1}(\mathrm{C}-\mathrm{Cl}) ;{ }^{1} \mathrm{H}$ NMR spectral data $\left(300.40 \mathrm{MHz}, \mathrm{Me}_{2} \mathrm{SO}_{6} \mathrm{~d}_{6}, \delta\right.$ ppm from TMS): $\delta$ 8.77 (s, 1H, N-H), 8.51-6.84 (m, 3H, Ar-H), 3.11 (q, $2 \mathrm{H}, \mathrm{CH}_{2}$ of $\mathrm{C}_{2} \mathrm{H}_{5}$ at $\left.\mathrm{C}-2\right), 1.31$ (t, $3 \mathrm{H}, \mathrm{CH}_{3}$ of $\mathrm{OC}_{2} \mathrm{H}_{5}$ at $\mathrm{C}-2), 2.65\left(\mathrm{q}, 2 \mathrm{H}, \mathrm{CH}_{2}\right.$ of $\mathrm{C}_{2} \mathrm{H}_{5}$ at $\left.\mathrm{C}-3\right), 1.43(\mathrm{t}, 3 \mathrm{H}$, $\mathrm{CH}_{3}$ of $\mathrm{C}_{2} \mathrm{H}_{5}$ at C-3); ${ }^{13} \mathrm{C} \mathrm{NMR} \mathrm{(75.45} \mathrm{MHz,} \mathrm{CDCl}_{3}, \delta$ ppm from TMS): $99.1(\mathrm{C}-2), 197.8\left(\mathrm{C}=\mathrm{O}\right.$ of $\mathrm{OC}_{2} \mathrm{H}_{5}$ at C-2), $30.3\left(\mathrm{CH}_{2}\right.$ of $\mathrm{C}_{2} \mathrm{H}_{5}$ at C-2), $7.6\left(\mathrm{CH}_{3}\right.$ of $\mathrm{C}_{2} \mathrm{H}_{5}$ at $\mathrm{C}-2), 158.1(\mathrm{C}-3), 23.9\left(\mathrm{CH}_{2}\right.$ of $\mathrm{C}_{2} \mathrm{H}_{5}$ at C-3), $9.1\left(\mathrm{CH}_{3}\right.$ of $\mathrm{C}_{2} \mathrm{H}_{5}$ at C-3), 121.5 (C-5), 135.0 (C-6), 120.8 (C-7), 125.5 (C-8); MS (FAB) $10 \mathrm{kV}, \mathrm{m} / \mathrm{z}$ (rel. int.): $299[\mathrm{M}]^{+}$, $301[\mathrm{M}+2]^{+}, 298$ (28), 270 (46), 242 (55), 264 (70), 57 (100); 'Anal. Calcd for $\mathrm{C}_{13} \mathrm{H}_{14} \mathrm{NO}_{3} \mathrm{SCl}$ : C, 52.08; $\mathrm{H}$, 4.67; N, 4.67, Found: C, 52.23; H, 4.70; N,4.76'.

2.4 General procedure for the synthesis of substituted $N$ - $\left(2^{\prime}, 3^{\prime}, 5^{\prime}\right.$-tri-O-benzoyl- $\beta$-D-ribofuranosyl) benzothiazines $(\mathbf{5} \boldsymbol{a}, \boldsymbol{b})$

To the solution of 4H-1,4-benzothiazine (3a, b) $(0.002 \mathrm{~mol})$ in $5 \mathrm{~mL}$ toluene, $\beta$-D-ribofuranose-1acetate-2,3,5-tribenzoate $(0.002 \mathrm{~mol})$ was added and the contents were refluxed under vacuum with stirring on an oil bath at $155-160^{\circ} \mathrm{C}$ for $15 \mathrm{~min}$. The vacuum was removed and reaction mixture was protected from moisture by fitting a guard tube. Stirring was further continued for $10 \mathrm{~h}$ and a vacuum was applied for $10 \mathrm{~min}$ after every $1 \mathrm{~h}$. The viscous mass obtained was dissolved in methanol, boiled for $10 \mathrm{~min}$ and cooled to room temperature. The reaction mixture was filtered and the filtrate was evaporated to dryness. The viscous residue thus obtained was dissolved in ether, filtered, concentrated and kept in refrigerator overnight to afford crystalline ribofuranosides.

2.4a $N$-(2',3',5'-tri-O-benzoyl- $\beta$-D-ribofuranosyl $)-8$ chloro-2-trifluoroacetyl-3-trifluoromethyl-5-methoxy4H-1,4-benzothiazine (5a): Red solid; m.p.: $86^{\circ} \mathrm{C}$; yield: 78\%, IR $(\mathrm{KBr}): v 1700(>\mathrm{C}=\mathrm{O}), 1170(\mathrm{C}-\mathrm{O}-$ C), 1355 and $1170 \mathrm{~cm}^{-1}\left(-\mathrm{CF}_{3}\right)$ and $795 \mathrm{~cm}^{-1}(\mathrm{C}-\mathrm{Cl})$; ${ }^{1} \mathrm{H}$ NMR spectral data $\left(300.40 \mathrm{MHz}, \mathrm{Me}_{2} \mathrm{SO}_{-} \mathrm{d}_{6}, \delta \mathrm{ppm}\right.$ from TMS): $\delta 8.56-7.54(\mathrm{~m}, 2 \mathrm{H}, \mathrm{Ar}-\mathrm{H}), 3.80(\mathrm{~s}, 3 \mathrm{H}$, $\left.-\mathrm{OCH}_{3}\right) ;{ }^{13} \mathrm{C} \mathrm{NMR}\left(75.45 \mathrm{MHz}, \mathrm{CDCl}_{3}, \delta \mathrm{ppm}\right.$ from TMS $): \delta 116.4(\mathrm{C}-2), 196.9(\mathrm{C}=\mathrm{O}$ at $\mathrm{C}-2), 129.0\left(\mathrm{CF}_{3}\right.$ at $\mathrm{C}-2), 136.7(\mathrm{C}-3), 114.5\left(\mathrm{CF}_{3}\right.$ at $\left.\mathrm{C}-3\right), 145.6(\mathrm{C}-5)$, $56.3\left(\mathrm{OCH}_{3}\right.$ at C-5), $113.5(\mathrm{C}-6), 118.8$ (C-7), 128.1 (C-8), $80.2\left(\mathrm{C}-1^{\prime}\right), 74.1\left(\mathrm{C}-2^{\prime}\right), 70.6\left(\mathrm{C}-3^{\prime}\right), 69.5(\mathrm{C}-$ $\left.4^{\prime}\right) ;{ }^{19} \mathrm{~F}$ NMR $\left(282.65 \mathrm{MHz}, \mathrm{CDCl}_{3}\right): \delta-62.35(\mathrm{~s}, 3 \mathrm{~F}$, $\mathrm{CF}_{3}$ ); $\mathrm{MS}$ (FAB) $10 \mathrm{kV}, \mathrm{m} / \mathrm{z}$ (rel. int.): $821[\mathrm{M}]^{+}, 823$ 
$[\mathrm{M}+2]^{+}, 723$ (49), 820 (34), 97 (100), 725 (65), 692 (53); 'Anal. Calcd for $\mathrm{C}_{38} \mathrm{H}_{26} \mathrm{NO}_{9} \mathrm{~F}_{6} \mathrm{SCl}$ : C, 55.51; $\mathrm{H}$, 3.16; N, 1.71 Found: C, 55.76; H,3.19; N, 1.81'.

$2.4 \mathrm{~b} \quad N-\left(2^{\prime}, 3^{\prime}, 5^{\prime}\right.$-tri-O-benzoyl- $\beta$-D-ribofuranosyl $)$ ethyl-8-chloro-5-methoxy-3-propyl-4H-1,4-benzothiazine-2-carboxylate (5b): Red solid; m.p.: $79^{\circ} \mathrm{C}$; yield: $85 \%$, IR (KBr): $v 1680(>\mathrm{C}=\mathrm{O}), 1160(\mathrm{C}-$ $\mathrm{O}-\mathrm{C})$, and $810 \mathrm{~cm}^{-1}(\mathrm{C}-\mathrm{Cl}) ;{ }^{1} \mathrm{H}$ NMR spectral data $\left(300.40 \mathrm{MHz}, \mathrm{Me}_{2} \mathrm{SO}_{-} \mathrm{d}_{6}, \delta\right.$ ppm from TMS): $\delta 8.32-$ $7.13(\mathrm{~m}, 2 \mathrm{H}, \mathrm{Ar}-\mathrm{H}), 3.78\left(\mathrm{~s}, 3 \mathrm{H},-\mathrm{OCH}_{3}\right), 1.95(\mathrm{t}, 2 \mathrm{H}$, $\mathrm{CH}_{2}$ (terminal) of $\mathrm{C}_{3} \mathrm{H}_{7}$ at C-3), 1.36 (sextet, $2 \mathrm{H}, \mathrm{CH}_{2}$ (centre) of $\mathrm{C}_{3} \mathrm{H}_{7}$ at $\left.\mathrm{C}-3\right), 0.94$ (t, $3 \mathrm{H}, \mathrm{CH}_{3}$ of $\mathrm{C}_{3} \mathrm{H}_{7}$ at C-3), 4.20 (q, 2H, $\mathrm{CH}_{2}$ of $\mathrm{OC}_{2} \mathrm{H}_{5}$ at $\left.\mathrm{C}-2\right), 1.30(\mathrm{t}, 3 \mathrm{H}$, $\mathrm{CH}_{3}$ of $\mathrm{OC}_{2} \mathrm{H}_{5}$ at $\left.\mathrm{C}-2\right) ;{ }^{13} \mathrm{C} \mathrm{NMR}\left(75.45 \mathrm{MHz}, \mathrm{CDCl}_{3}\right.$, $\delta$ ppm from TMS $): \delta 106.0(\mathrm{C}-2), 165.2(\mathrm{C}=\mathrm{O}$ at $\mathrm{C}-2)$, $58.9\left(\mathrm{CH}_{2}\right.$ of $\mathrm{OC}_{2} \mathrm{H}_{5}$ at $\left.\mathrm{C}-2\right), 13.8\left(\mathrm{CH}_{3}\right.$ of $\mathrm{OC}_{2} \mathrm{H}_{5}$ at C-2), $144.0(\mathrm{C}-3), 31.8\left(\mathrm{CH}_{2}\right.$ (terminal) of $\mathrm{C}_{3} \mathrm{H}_{7}$ at C-3), $18.1\left(\mathrm{CH}_{2}\right.$ (middle) of $\mathrm{C}_{3} \mathrm{H}_{7}$ at C-3), $13.8\left(\mathrm{CH}_{3}\right.$ (terminal) of $\mathrm{C}_{3} \mathrm{H}_{7}$ at C-3), $144.5(\mathrm{C}-5), 56.1\left(\mathrm{OCH}_{3}\right.$ at C-5), 113.1 (C-6), 118.8 (C-7), 127.6 (C-8), 81.4 $\left(\mathrm{C}-1^{\prime}\right), 75.5\left(\mathrm{C}-2^{\prime}\right), 72.2\left(\mathrm{C}-3^{\prime}\right), 70.3\left(\mathrm{C}-4^{\prime}\right)$; MS (FAB) $10 \mathrm{kV}, \mathrm{m} / \mathrm{z}$ (rel. int.): $771[\mathrm{M}]^{+}, 773[\mathrm{M}+2]^{+}, 770(41)$, 697 (30), 692 (54), 73 (100), 665 (60); 'Anal. Calcd for $\mathrm{C}_{41} \mathrm{H}_{38} \mathrm{NO}_{10} \mathrm{SCl}: \mathrm{C}, 63.77 ; \mathrm{H}, 4.93 ; \mathrm{N}, 1.81$, Founds: C, 63.98; H, 4.98; N, 1.95'.

\section{Biological activity}

\subsection{In vitro antibacterial and antifungal activity}

3.1a Antibacterial activity: Antibacterial activity was tested against $S$. aureus, B. subtilis (Gram positive) and E. coli, Pseudomonas aeruginosa (Gram negative) microorganisms using paper disc diffusion method using nutrient agar medium. The paper disc diffusion method of assay of drug potency is based on the measurement of the zone of microbial growth inhibition surroundings discs containing various concentrations of test compounds, which are placed on the surface of a solid nutrient previously inoculated with the culture of suitable microorganism. Inhibition produced by the test drug is compared with that produced by known concentration of reference standard.

In this method, paper disc impregnated with compounds dissolved in solvent DMF at concentrations 25,50 and $100 \mu \mathrm{gmL}^{-1}$. Then the disc impregnated with the solution was placed on the surface of the media inoculated with the bacterial strain. The plates were incubated at $35^{\circ} \mathrm{C}$ for $24 \mathrm{~h}$ for bacterial cultures. After incubation, the zones of inhibition around the disc were observed. Each testing is done in triplicate. Ciprofloxacin at conc. $50 \mathrm{\mu gmL}^{-1}$ was used as standard drug for antibacterial activity. Results were interpreted in terms of diameter ( $\mathrm{mm}$ ) of zone of inhibition. The \% activity index for the compound was calculated by the formula as under:

$$
\begin{aligned}
& \text { \% Activity Index } \\
& =\frac{\text { Zone of inhibition by test compound (diameter) }}{\text { Zone of inhibition by standard (diameter) }} \\
& \quad \times 100 .
\end{aligned}
$$

3.1b Antifungal activity: Antifungal activity of synthesized compounds was tested on following fungal strains: A. niger, C. albican, using disc diffusion method. In the disc-diffusion method, disc impregnated with compounds dissolved in solvent DMF at concentrations 25,50 and $100 \mu \mathrm{gmL}^{-1}$ were spread over microorganism culture in nutrient agar medium. The plates were incubated at $25^{\circ} \mathrm{C}$ for $48 \mathrm{~h}$ for fungal strains. After incubation, the growth inhibiting zones around the disc were observed. Growth inhibiting zone indicates that the compounds inhibit growth of microorganism. Each experiment is done in triplicate. Griseofulvin at concentration $50 \mathrm{\mu gmL}^{-1}$ was used as standard drug for antifungal activity. Results were interpreted in terms of diameter $(\mathrm{mm})$ of zone of inhibition. The percentage inhibition was calculated by the following equation

$$
\% \text { Inhibition }=(\mathrm{C}-\mathrm{T}) 100 / \mathrm{C},
$$

where $\mathrm{C}$ and $\mathrm{T}$ are the diameters of the fungal colony in the control and the test plates, respectively.

\subsection{Minimal inhibitory concentrations}

Minimum inhibitory concentrations (MICs) are defined as the lowest concentration of antimicrobials that will inhibit the visible growth of a microorganism after overnight incubation at $37^{\circ} \mathrm{C}$. Determination of the MIC is a semiquantitative test, which gives an approximate idea of the least concentration of an antimicrobial (test) solution needed to parent microbial growth. The MIC was determined by the liquid dilution method. Two Gram positive (Staphylococcus aureus and Bacillus subtilis) and two Gram negative (Escherichia coli and Pseudomonas aeruginosa) were used as quality control strains. Candida albicans and Aspergilius niger were tested for the antifungal activities of the compounds. Ciprofloxacin and Griseofulvin were used as standard antibacterial and antifungal agents. The stock solutions of test compounds with 1 to $20 \mu \mathrm{gmL}^{-1}$ 


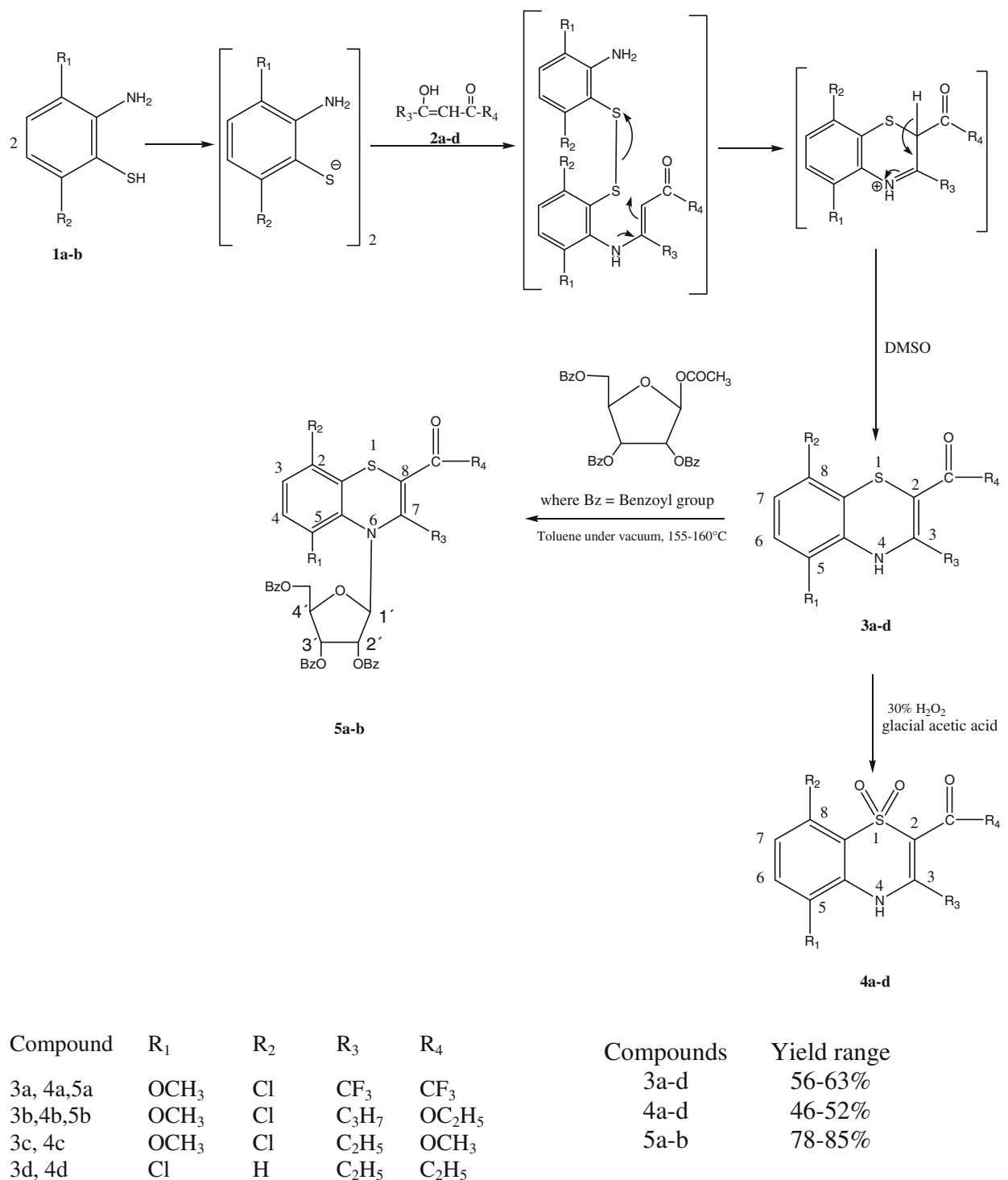

Scheme 1. Synthesis of substituted 4H-1,4-benzothiazines.

concentrations were prepared with aqueous methanol. Inoculums of the overnight culture were prepared. In a series of tubes, $1 \mathrm{~mL}$ each of stock solutions of test compound with different concentration are taken and $0.4 \mathrm{~mL}$ of the inoculums was added to each tube. Further $4.0 \mathrm{~mL}$ of sterile water was added to each of the test tubes. These test tubes were incubated for $22-24 \mathrm{~h}$ and observed for the presence of turbidity. The absorbance of the suspension of the inoculums was observed with spectrophotometer at $555 \mathrm{~nm}$. The end result of the test was the minimum concentration of antimicrobial (test) solutions, which gave clear solution, i.e., no visual growth.

\subsection{Anthelmintic activity}

Anthelmintic studies were carried out against Eudrilus species of earthworms by Garg and Atal method at $4 \mu \mathrm{gmL}^{-1}$ concentrations. Suspensions of samples were prepared by triturating synthesized compounds $(200 \mathrm{mg})$ with Tween $80(0.5 \%)$ and distilled water and the resulting mixtures were stirred using a mechanical stirrer for $30 \mathrm{~min}$. The suspensions were diluted to contain $0.4 \% \mathrm{w} / \mathrm{v}$ of the test samples. Suspension of reference drug mebendazole was prepared with same concentration in a similar way. Three sets of five earthworms of almost similar sizes ( 3 inch in length) were placed in petri plates of 4 inch diameter containing $50 \mathrm{~mL}$ of suspension of test sample and reference drug at room temperature. Another set of five earthworms was kept as control in $50 \mathrm{ml}$ suspension of distilled water and Tween $80(0.5 \%)$. The paralyzing and death times were noted and their mean was calculated for triplicate sets. The death time was ascertained by placing the earthworms in warm water $\left(50^{\circ} \mathrm{C}\right)$, which stimulate the movement, if the worm was alive. 


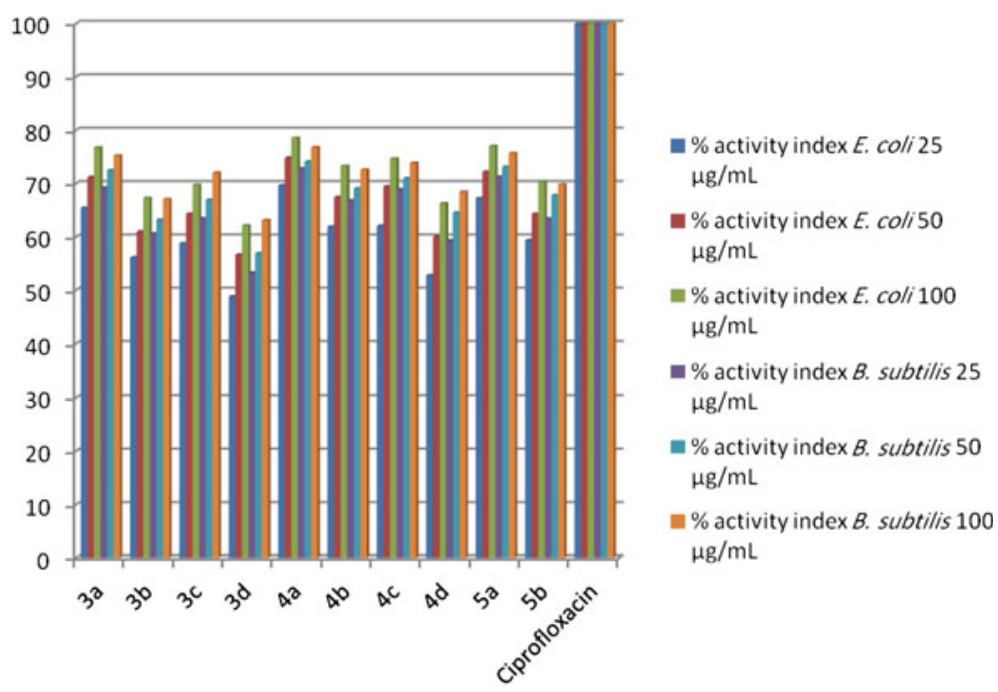

Figure 1. \% Activity index of E. coli and B. subtilis.

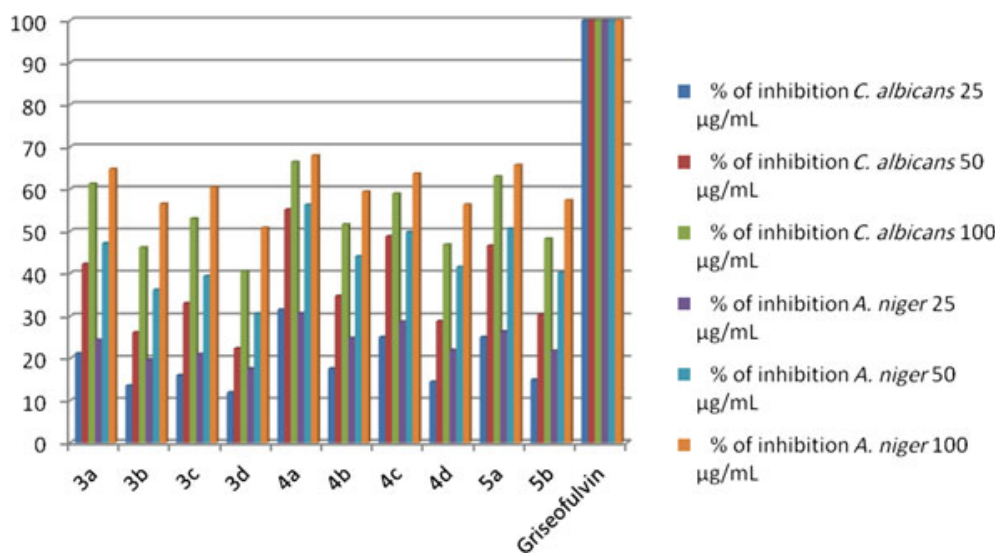

Figure 2. \% Activity index of $P$. aeruginosa and $S$. aureus.

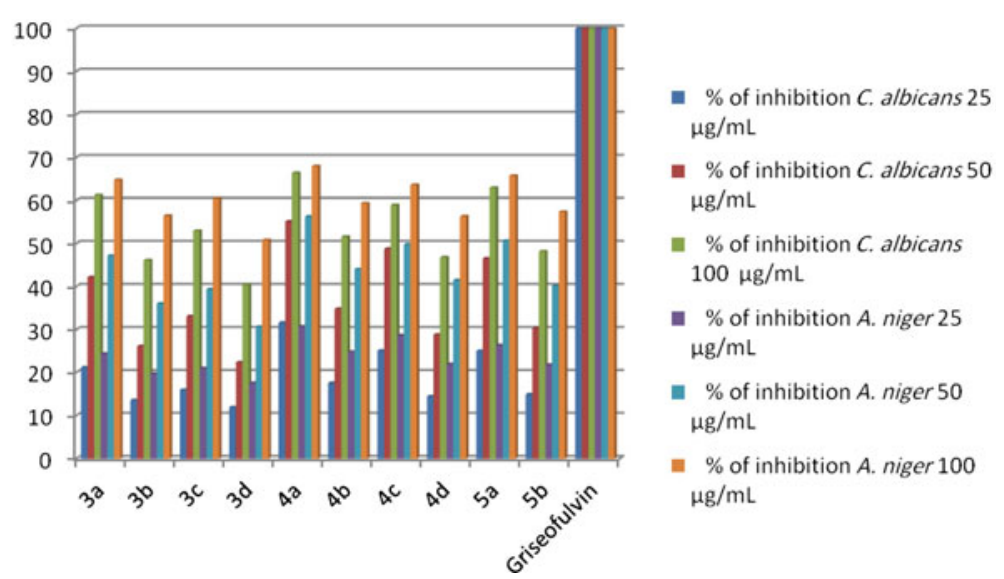

Figure 3. \% Inhibition of C. albicans and A. niger. 


\section{Results and discussion}

Substituted 2-amino-6-chloro-3-methoxy/2-amino-3chlorobenzenethiol (1a-b) and the appropriate $\beta$-diketones/ $\beta$-ketoesters (2a-d) were refluxed in dimethyl sulphoxide which results in oxidative cyclization. This reaction proceeds with the formation of an intermediate enaminoketone. The bis-(2aminophenyl)disulphides were obtained which then cyclizes to $4 H-1,4$-benzothiazine (3a-d) by the scission of sulphur-sulphur bond, due to high reactivity of $\alpha$-position of enaminoketone system towards nucleophilic attack. On refluxing the compound (3a-d), with $30 \%$ hydrogen peroxide in glacial acetic acid, their corresponding sulphones (4a-d) were obtained. Compounds (3a-b) were treated with $\beta$-D-ribofuranose-1acetate-2,3,5-tribenzoate in toluene stirred in vacuum in an oil both at $155-160^{\circ} \mathrm{C}$ for $10 \mathrm{~h}$ to form their ribofuranosides $(\mathbf{5} \mathbf{a}-\mathbf{b})$. The structures proposed for the synthesized compounds were elucidated by spectroscopic data and elemental analysis. All the synthesized compounds were also screened for their antioxidant and antimicrobial activities (scheme 1).

A series of novel heterocyclic compounds (3a-d) and $(\mathbf{4 a}-\mathbf{d})$ were synthesized. All the compounds tested against for their in vitro antibacterial activity against the four strains of bacteria (two Gram-ve E.coli, Pseudomonas aeruginosa and two Gram+ve Bacillus subtilis, Staphylococcus aureus) and antifungal activity against the two strains of fungi (C. albicans and $A$. niger). The results have been summarized in figures 1 , 2 and 3. The results show that all the compounds act as antimicrobial agent against selected bacteria and fungi. The antibacterial and antifungal activities increase with increase concentration of test compounds. The minimum inhibitory concentration (MIC) of the compounds varies from 9.25 to $17.30 \mu \mathrm{gmL}^{-1}$ (tables 1 and 2). Among compounds of the obtained series, 3a, 4a, $\mathbf{4 c}$ and 5a showed good activity and remaining showed moderate activity against bacteria $E$. coli. Compounds 4a showed good and remaining moderate activity against bacteria $B$. subtilis. For bacteria $P$. aeruginosa,

Table 1. Minimum inhibitory concentrations $\left(\mu \mathrm{gmL}^{-1}\right)$ of synthesized compounds.

\begin{tabular}{lcccc}
\hline & \multicolumn{3}{c}{ Bacterial minimal inhibitory concentrations $\left(\mu \mathrm{gmL}^{-1}\right)$} \\
\cline { 2 - 4 } Compound No. & E. coli & B. subtilis & P. aeruginosa & S. aureus \\
\hline 3a & $10.10 \pm 0.22$ & $12.00 \pm 0.10$ & $10.15 \pm 0.27$ & $11.30 \pm 0.09$ \\
$\mathbf{3 b}$ & $13.20 \pm 0.26$ & $16.10 \pm 0.15$ & $11.40 \pm 0.23$ & $17.30 \pm 0.32$ \\
$\mathbf{3 c}$ & $13.00 \pm 0.17$ & $15.80 \pm 0.27$ & $11.15 \pm 0.31$ & $16.40 \pm 0.33$ \\
$\mathbf{3 d}$ & $14.15 \pm 0.35$ & $16.70 \pm 0.20$ & $12.16 \pm 0.19$ & $17.26 \pm 0.17$ \\
$\mathbf{4 a}$ & $09.36 \pm 0.28$ & $11.10 \pm 0.19$ & $09.25 \pm 0.24$ & $10.52 \pm 0.19$ \\
$\mathbf{4 b}$ & $11.30 \pm 0.20$ & $15.50 \pm 0.22$ & $11.09 \pm 0.18$ & $16.70 \pm 0.27$ \\
$\mathbf{4 c}$ & $11.05 \pm 0.29$ & $15.15 \pm 0.26$ & $10.80 \pm 0.35$ & $15.94 \pm 0.33$ \\
$\mathbf{4 d}$ & $12.50 \pm 0.32$ & $16.30 \pm 0.16$ & $12.45 \pm 0.28$ & $16.90 \pm 0.25$ \\
$\mathbf{5 a}$ & $09.78 \pm 0.19$ & $11.82 \pm 0.29$ & $09.67 \pm 0.34$ & $11.00 \pm 0.24$ \\
$\mathbf{5 b}$ & $12.22 \pm 0.31$ & $15.72 \pm 0.17$ & $11.16 \pm 0.25$ & $17.12 \pm 0.21$ \\
Ciprofloxacin & $04.10 \pm 0.10$ & $04.90 \pm 0.13$ & $03.85 \pm 0.15$ & $04.90 \pm 0.11$ \\
\hline
\end{tabular}

Table 2. MIC $\left(\mu \mathrm{gmL}^{-1}\right)$ of synthesized compounds.

\begin{tabular}{lcc}
\hline & \multicolumn{2}{c}{$\begin{array}{c}\text { Fungal minimal inhibitory } \\
\text { concentrations }\left(\mu \mathrm{gmL}^{-1}\right)\end{array}$} \\
\cline { 2 - 3 } Compound No. & C. albicans & A. niger \\
\hline $\mathbf{3 a}$ & $10.40 \pm 0.26$ & $10.13 \pm 0.31$ \\
$\mathbf{3 b}$ & $13.10 \pm 0.22$ & $15.40 \pm 0.16$ \\
$\mathbf{3 c}$ & $12.35 \pm 0.19$ & $15.90 \pm 0.29$ \\
$\mathbf{3 d}$ & $14.30 \pm 0.27$ & $16.10 \pm 0.32$ \\
$\mathbf{4 a}$ & $10.00 \pm 0.35$ & $09.39 \pm 0.17$ \\
$\mathbf{4 b}$ & $11.20 \pm 0.21$ & $15.00 \pm 0.26$ \\
$\mathbf{4 c}$ & $10.90 \pm 0.23$ & $14.30 \pm 0.32$ \\
$\mathbf{4 d}$ & $13.75 \pm 0.31$ & $15.60 \pm 0.20$ \\
$\mathbf{5 a}$ & $10.26 \pm 0.18$ & $09.77 \pm 0.29$ \\
$\mathbf{5 b}$ & $12.13 \pm 0.34$ & $15.14 \pm 0.21$ \\
Griseofulvin & $03.10 \pm 0.08$ & $04.80 \pm 0.10$
\end{tabular}


Table 3. Anthelmintic activity of synthesized compound.

\begin{tabular}{|c|c|c|c|c|c|c|}
\hline \multirow[b]{3}{*}{ Compound No. } & \multicolumn{6}{|c|}{ Time (min) } \\
\hline & \multicolumn{3}{|c|}{ Paralyzing time } & \multicolumn{3}{|c|}{ Death time } \\
\hline & $200 \mathrm{mgmL}^{-1}$ & $100 \mathrm{mgmL}^{-1}$ & $50 \mathrm{mgmL}^{-1}$ & $200 \mathrm{mgmL}^{-1}$ & $100 \mathrm{mgmL}^{-1}$ & $50 \mathrm{mgmL}^{-1}$ \\
\hline $3 \mathbf{a}$ & $11.00 \pm 0.67$ & $14.83 \pm 0.83$ & $21.55 \pm 1.00$ & $15.53 \pm 0.69$ & $20.50 \pm 0.50$ & $31.03 \pm 0.90$ \\
\hline 3b & $15.00 \pm 0.77$ & $17.00 \pm 1.00$ & $23.45 \pm 0.93$ & $19.31 \pm 1.00$ & $27.16 \pm 0.76$ & $35.75 \pm 0.57$ \\
\hline $3 c$ & $13.26 \pm 1.08$ & $16.00 \pm 1.10$ & $22.50 \pm 0.50$ & $18.16 \pm 0.76$ & $26.10 \pm 0.73$ & $34.50 \pm 0.50$ \\
\hline 3d & $15.16 \pm 1.24$ & $18.50 \pm 1.00$ & $24.56 \pm 0.70$ & $20.16 \pm 0.90$ & $29.16 \pm 0.67$ & $38.83 \pm 0.98$ \\
\hline $4 \mathbf{a}$ & $08.79 \pm 0.67$ & $13.50 \pm 1.00$ & $19.48 \pm 0.77$ & $13.15 \pm 0.67$ & $19.00 \pm 0.66$ & $28.16 \pm 0.76$ \\
\hline $4 b$ & $12.85 \pm 1.22$ & $16.66 \pm 0.94$ & $22.78 \pm 0.60$ & $15.40 \pm 0.77$ & $24.65 \pm 0.79$ & $35.23 \pm 0.91$ \\
\hline $4 c$ & $12.00 \pm 1.00$ & $15.00 \pm 0.90$ & $22.20 \pm 1.00$ & $20.63 \pm 0.62$ & $24.13 \pm 1.09$ & $34.12 \pm 0.60$ \\
\hline 4d & $13.16 \pm 0.75$ & $18.00 \pm 0.78$ & $25.00 \pm 0.70$ & $19.12 \pm 0.60$ & $27.08 \pm 1.00$ & $38.43 \pm 1.00$ \\
\hline $5 \mathbf{a}$ & $09.54 \pm 0.88$ & $14.00 \pm 1.10$ & $20.03 \pm 0.68$ & $15.16 \pm 1.24$ & $19.50 \pm 0.50$ & $28.90 \pm 1.05$ \\
\hline $5 b$ & $12.20 \pm 1.00$ & $16.50 \pm 1.20$ & $23.36 \pm 1.00$ & $17.33 \pm 1.52$ & $27.00 \pm 1.10$ & $35.50 \pm 0.89$ \\
\hline Mebendazole & $12.50 \pm 1.04$ & $16.00 \pm 0.98$ & $21.80 \pm 1.34$ & $15.26 \pm 0.84$ & $22.65 \pm 0.90$ & $30.55 \pm 1.00$ \\
\hline
\end{tabular}

compounds 3a, $\mathbf{4 a}, \mathbf{4 c}$ and $\mathbf{5 a}$ showed good activity and remaining showed moderate activity. Compounds $\mathbf{4 a}$ and 5a showed good and remaining showed moderate activity against bacteria $S$. aureus.

Compounds 3a, 4a, 4c and 5a showed good activity against fungi $C$. albicans. For fungi $A$. niger, compounds 3a, $\mathbf{4 a}$ and $\mathbf{5 a}$ showed good activity and remaining showed moderate activity.

The above screened compounds were tested for anthelmintic activity. The results have been summarized in table 3 . The results showed that compounds 3a, 4a, 4c and 5a showed significant paralytic time than standard drug Mebendazole, at given concentrations. Test compounds $\mathbf{5 b}$ show better death time of earthworms with that of standard drug Mebendazole. The synthesized compounds in overall estimation confirms the better activity against Eudrilus species of earthworms.

\section{Conclusion}

The present paper is focused on the synthesis of novel heterocyclic compounds as possible antibacterial and antifungal agents. The structures of synthesized compounds are well-supported by spectral data and elemental analysis. In the preparation of ribofuranosides (5a-b), ribosylation takes place mostly by replacing hydrogen atom attach to nitrogen in 4H-1,4benzothiazines (3a-d).

The present study elucidated that the synthesized compounds showed good anthelmintic activity. Compounds 3a, 4a, c and 5a showed significant paralytic time and compounds $\mathbf{5} \mathbf{b}$ showed better death time of earthworms with that of standard drug Mebendazole. In antimicrobial activity, 4a exhibited good antibacterial activities against four strains of bacteria. Compounds (4a-d) exhibited significant antibacterial and antifungal activities as compared to their benzothiazines (3ad), respectively due to electron withdrawing effect of oxygen in (4a-d). In general, the presence of electron withdrawing group on the aromatic ring increases the antimicrobial activities of tested compounds when compared to compounds having electron donating groups.

\section{Acknowledgements}

The authors are thankful to the Department of Chemistry, University of Rajasthan, Jaipur, for providing laboratory facilities and spectral data analysis. Authors are also thankful to Rajiv Academy for Pharmacy, Mathura for assistance in carrying out the biological activities. The University Grants Commission (UGC), New Delhi is duly acknowledged for financial support through Major Research Project and UGC Research Award Scheme.

\section{References}

1. Clercq E D 1985 Nucleos. Nucleot. Nucl. 4(1) 3

2. Gupta R R 1988 Phenothiazines and 1, 4-benzothiazines chemical and biomedical aspects, Amsterdam: Elsevier, 160

3. Gupta V, Gautam R K, Jain S K and Gupta R R 1990 Phosphorus Sulphur 47(1) 225

4. Gupta A, Saraswat V, Mukherji S K and Gupta R R 1993 Phosphorus Sulphur 85(1) 101

5. Kumar N, Singh G and Yadav A K 2001 Heteroatom. Chem. 12(1) 52

6. Sharma P R, Gupta V, Gautam D C and Gupta R R 2003 Phosphorus Sulphur 178(7) 1483

7. Gautam N, Hans D and Gautam D C 2005 Oriental J. Chem. 21(2) 299 
8. Kachee T L, Gupta V, Gautam D C and Gupta R R 2005 Phosphorus Sulphur 180(10) 2225

9. Gautam V, Sharma M, Panwar M, Gautam N, Kumar A, Sharma I K and Gautam D C 2009 Phosphorus Sulphur 184(11) 3090

10. Gupta S, Ajmera N, Meena P, Gautam N, Kumar A and Gautam D C 2009 Jordan J. Chem. 4(3) 209

11. Cuendet M, Hostettmann K, Potterat O and Dyatmiko W 1997 Helv. Chim. Acta 80(4) 1144
12. Re R, Pellegrini N, Proteggente A, Pannala A, Yang M and Rice-Evans C 1999 Free Radical Biol. Med. 261231

13. Braca A, Tommasi N D, Basi L D, Pizza C, Politi M and Morelli I 2001 Nat. Prod. J. 64(7) 892

14. Kolaczowski M, Michalak K and Motoashi N 2003 Int. J. Antimicrob. Agents 22(3) 279

15. Omar K, Geronikaki A, Zoumpoulakis P, Camoutsis C, Sokovic M, Ciric A and Glamoclija J 2010 Biol. Med. 18426 